\title{
Isolation and identification of azo dye degrading microbes using 16s $r$ RNA sequencing
}

\author{
V. Pushpa* \\ ty, Jnanasahyadri, Shankaraghatta, Shivamogga (Karnataka), India

\section{K. Yogendra} \\ ty, Jnanasahyadri, Shankaraghatta, Shivamogga (Karnataka), India

\section{K. M. Mahadevan} \\ University, Kadur ( $T$ ), Chickmagalur (D) (Karnataka), India

\section{Mahesh} \\ Azyme Bioscience Pvt Ltd, Bangalore (Karnataka), India \\ *Corresponding author. E-mail: pv92233@gmail.com
}

Department of P. G. Studies and Research in Environmental Science, Kuvempu Universi-

Department of P. G. Studies and Research in Environmental Science, Kuvempu Universi-

Department of P. G Studies and Research in Chemistry, P.G. Centre Kadur, Kuvempu

\begin{abstract}
The aim of the present study was to isolate and identify azo dye degrading microbes using 16s $r$ RNA sequencing. For this, ten effluent and fifty soil samples were collected from textile industry from a discharge panel of textile industries near Peenya and Magadi road Industrial area, Bengaluru, and dying industries near Kerur, Bagalkot, Karnataka, India. The $\mathrm{pH}$, temperature, BOD, COD, Odor, Total dissolved solid (TDS), Total suspended solids (TSS), Chemical oxygen demand (COD), Biological oxygen demand (BOD), Dissolved Oxygen (DO), and Total Hardness values were very high when compared with the values given by the Bureau of Indian Standards. Pure cultures were screened on the basis of colony morphology. Three different types of unique cultures were selected and named as isolates S1, S2 and S3. Outof 6 dyes viz. Corafast blue, Corafast red, Red 3BN, Solophenyl Brown, RemazoleRG, Rubin M2B used, isolate S1 showed degradation on the maximum number of dyes Red 3BN, Corafast blue, Corafast red, in comparison to other isolates (isolates S2 and S3). Thus, isolate S1 was used for the further studies. For this study Red 3BN dye was chosen. The isolated bacterium was gram positive Bacilli. In the biochemical characterization, the isolate was partially confirmed as Bacillus sp. Further, the selected isolate was identified by sequencing the 16S rRNA sequencing. The bacterial isolate was identified as Bacillus species exhibiting $99 \%$ similarity, the phylogenic relationship of $16 \mathrm{~S}$ ribosomal RNA gene, partial sequence of the isolated strain and species related to Bacillus species in the gene bank database. Thus, this organism may be used significantly in effluent treatment such as textile, paper, ink and other industries.
\end{abstract}

Keywords: Azo dye, Bacillus species, Degradation, Effluent, Fermentation, Pure culture

\section{INTRODUCTION}

Azo dyes have been widely used as dyestuffs in cosmetics, foods, printing and textile materials. These dyes are the largest class of commercially available synthetic dyes and wide applications in textiles, food, cosmetics, plastic, laboratories, leather, paper printing, colour photography, pharmaceutical and toy industries(Mathur and Bhatnagar, 2007; Pant et al., 2008; Laowansiriet al.,2008). Several physico-chemical techniques have been proposed for treatment of colored textile effluents. These include adsorption on different materials, oxidation and precipitation by Fenton's reagent, bleaching with chloride or ozone photo

\section{Article Info}

DOI:10.31018/jans.v11i2.2025 Received: February 19, 2019 Revised: March 22, 2019 Accepted: April 3, 2019

\section{How to Cite}

Pushpa, V. et al. (2019). Isolation and identification of azo dye degrading microbes using 16s r RNA sequencing. Journal of Applied and Natural Science, 11(2): 245- 249 https://doi.org/10.31018/ jans.v11i2.2025 
and azoreductase have been shown to degenerate azo dyes. But the stable operation of continuous fungal bioreactors for the treatment of synthetic dye solutions have been achieved, application of fungi for the removal of dyes from textile wastewaters faces many problems such as production of large volumes, the nature of synthetic dyes, and control of biomass (Nigam et al., 2000; Robinson et al., 2001; Stolz, 2001). The bacterial reduction of the azo dye is usually nonspecific and bacterial decolorization is faster (Sudhaet al., 2014). The objective of the present study was to analyze the physico-chemical characterization of textile dye effluents and isolate and characterization of dye degrading bacteria from dye effluents and soil.

\section{MATERIALS AND METHODS}

Sample collection: For the isolation of dye degrading microorganisms, 50 soil samples were collected in sterilized ziplock polythene covers and 10 effluent samples in sterilized screw capped bottles from a discharge panel of textile industries near Peenya and Magadi road industrial area, Bengaluru, and dying industries near Kerur, Bagalkot , Karnataka, India. Collected effluent samples were named as S1, S2, S3, S4, S5 S6, S7, S8, S9, S10 and brought to laboratory.

Physico-chemical property analysis: The collected effluent samples were analyzed to determine their physico-chemical parameters. The various parameters such as Temperature, $\mathrm{pH}$, Color, Odor, Total dissolved solid (TDS), Total suspended solids (TSS), Chemical oxygen demand (COD), Biological oxygen demand (BOD), Dissolved Oxygen (DO), and Total Hardness were analyzed in the laboratory by the standard protocol(Aneja, 2003).

Isolation of bacteria from soil and effluent samples: The organism was isolated from soil and effluent samples by pour plate method. In this process soil samples were dissolved in $8 \%$ saline and effluent samples were pipetted into steriletest tubes, $15 \mathrm{ml}$ of minimal agar media [Potassium di hydrogen phosphate $3.0 \mathrm{~g}$, Disodium hydrogen phosphate $6.0 \mathrm{~g}$, Sodium chloride $5.0 \mathrm{~g}$, Ammonium chloride $2.0 \mathrm{~g}$, Magnesium sulphate $0.1 \mathrm{~g}$, Agar $15 \mathrm{~g}$, Distilled water $1000 \mathrm{ml}$ ) along with different dyes such asCorafast blue, Corafast red, Red 3BN, SolophenylBrown,Remazole RG , Rubin M2B and incubatedat $37^{\circ} \mathrm{C}$ for 48 hours. After the incubation, the clear zone was observed around the colonies which indicated the degradationandonlythese isolates were taken for the study.

Screening of bacterial isolates for dye decolorization: For screening of the dye degrading bacteria,the isolates (2 isolates from soil and one from effluent) showing clear zone around the colonies were streaked onto minimal agar medium along with respective dyes and incubated at $37^{\circ} \mathrm{C}$ for 24 hours. After incubation, maximum degradation showed colonies were inoculated into the minimal broth and analyzed by Spectrophotomeric method. For this process, $100 \mathrm{ml}$ of minimal broth along with the dyes $(10 \mathrm{mg} / 100 \mathrm{ml})$ was inoculatedwith loopful of isolated bacterial culture. The culture flasks were incubated on orbital shaker with $150 \mathrm{rpm}$, at $37^{\circ} \mathrm{C}$.Flasks without inoculum kept as control. Absorbance values were measured Spectrphotometrically at580 $\mathrm{nm}$ for blue dye and 530nm for Red dye to estimate the decolorization process. The rat of decolorization was calculated using the following formula.

$\%$ Decolorization=

$\frac{\text { Intial absorbance walue-final absorbance value }}{\text { Intial } \mathrm{ahsorbance} \text { value }} \times 100$

........Eq. 1

Identification of bacteria: Three different bacterial isolates showed degradation and were named as S1, S2 and S3. Among these S1 showed maximum degradation and was identified on the basis of morphological, biochemical and 16s rRNA sequence.

Morphological characterization of isolated colonies from collected samples: The morphological characterization gave an idea of the size, shape, arrangement of bacterial cells.

Biochemical characterization of isolated bacteria: Colonies were subjected to biochemical tests such as Indole production, Methyl red, VogesProskauer, Citrate utilization, Triple sugar iron utilization, Carbohydrate fermentation tests such as Glucose, lactose and enzymatic tests such as Starch hydrolysis, Gelatin hydrolysis, Casein hydrolysis, Urease utilization, Catalase production, Oxidase production, Nitrate reduction tests by following the methodology of Holding and Collee1971).

Molecular identification of the bacterial Isolate Isolation of Genomic DNA: $25 \mathrm{ml}$ of LB broth was prepared, isolated organism was inoculated and incubated at $37^{\circ} \mathrm{C}$ for 24 hours. After the incubation $1 \mathrm{ml}$ of culture was taken in an eppendroff tube, centrifuged at $6000 \mathrm{rpm}$ for 10 minutes. Pellets were taken and $500 \mu$ l of lysis buffer (50mMTris HCL, 20mM EDTA, $1.25 \%$ SDS) added. Gently vortexed and incubated at $60^{\circ}-65^{\circ} \mathrm{C}$ for one hour. Allowed to room temperature and $200 \mu \mathrm{l}$ of $5 \mathrm{M}$ Sodium acetate was added. Incubated in cold conditions for 10 minutes and centrifuged at 10000 rpm for 10 minutes. Then, the double volume of ethanol was added to the collected supernatant and incubated for 10 minutes at room temperature. Centrifuged at 12000 rpm for 10 minutes. Pellets were collected, dissolved in $50 \mu \mathrm{l}$ of TE buffer (10mM TrisHCl, 1mM EDTA).

PCR reaction: The molecular signatures of the isolate were studied by partial sequencing of $16 \mathrm{~S}$ rRNA gene and comparing it with known sequences. The set of universal primers; and 
F5'AGAGTTTGATCCTGGCTCAG3'R5'TACGGT TACCTTGTTACGACTT3' was used to amplify the desired sequence.

The following reaction mixture was used to amplify $16 \mathrm{~S}$ rRNA of isolates. The total reaction volume was $50 \mu \mathrm{l}$ for each reaction. The PCR reaction mixture was as follows: DNS sample $3 \mu \mathrm{l}, 5 \mathrm{X}$ Phusion HF buffer 10 $\mu$, and Forward primer2 $\mu \mathrm{l}$ $(0.05 \mu \mathrm{M})$ Reverse primer $2 \mu \mathrm{l}(0.05 \mu \mathrm{M})$, dNTPs $(200 \mu \mathrm{M}) 5 \mu \mathrm{l}$, Phusion Polymerase 0.5 I Distilled

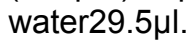

PCR conditions: PCR amplification was performed in $95^{\circ} \mathrm{C}$. Differentannealing temperatures were tested (from 46 to $56{ }^{\circ} \mathrm{C}$ ). The best annealing temperature was 30 second at $55^{\circ} \mathrm{C}$ where it produced only one high intense DNA ampilicon. The optimum program was one cycle at $95^{\circ} \mathrm{Cfor}$ five minutes, and then 30 cycles were performed as follows: thirty seconds at $98^{\circ} \mathrm{C}$ for denaturation, thirty seconds at $55^{\circ} \mathrm{C}$ for annealing, one minute at $72{ }^{\circ} \mathrm{C}$ for elongation, and then 10 minutes at $72^{\circ} \mathrm{C}$ for final extension. The reaction mixtures were held at $4{ }^{\circ} \mathrm{C}$ until used. After completion of PCR run $5 \mu \mathrm{l}$ PCR product on $1.2 \%$ agarose gel to confirm amplification and the amplified sample was sent to Eurofins Genomics India Pvt Ltd Bangalore for Sequencing.

\section{RESULTS AND DISCUSSION}

Total dissolved solids were present in S8 (3200 $\mathrm{mg} / \mathrm{l})$ and $S 9(1279 \mathrm{mg} / \mathrm{l})$ samples respectively which were above the BIS standards $(2100 \mathrm{mg} / \mathrm{l})$. High concentration of dissolved solids affects the density of water and influences solubility of gases like oxygen in water and osmoregulation of freshwater organisms (Sriramet al 2015, Thoker Farook et al 2012). The minimum total suspended solids (TDS) were recorded at S5 $(120 \mathrm{mg} / \mathrm{l})$ while the maximum at $S 10(210 \mathrm{mg} / \mathrm{l})$, the standard limit prescribed is $100 \mathrm{mg} / \mathrm{l}$.The maximum chemical oxygen demand (COD) were observed from S7 $(929 \mathrm{mg} / \mathrm{l})$ and minimum in S5(667mg/l) which was much higher than maximum recommended limit of Fedaral Environmental Quality and Bureau Indian Standards, it's impacted the receiving water body to some extent and its effects on the quality of freshwater and subsequently cause harm to aquatic life (Thoker Farook et al., 2012, Manikandan et al., 2012,Rajeswariet al.,2013). The maximum biological oxygen demand (BOD) was observed from S5 (310 mg/l) and minimum in S8 $(123 \mathrm{mg} / \mathrm{l})$ and the standard recommendation (BIS) is $350 \mathrm{mg} / \mathrm{l}$. Dissolved oxygen is a fundamental requirement for aquatic life (Sofia Nosheen 2000). The maximum dissolved oxygen (DO) was recorded in S9 $(190 \mathrm{mg} / \mathrm{l})$ and minimum in S3 $(106 \mathrm{mg} / \mathrm{I})$ samples comparatively with other effluent samples (Table 1).

Isolation of bacteria from soil samples: About 50 different bacterial isolates were isolated from

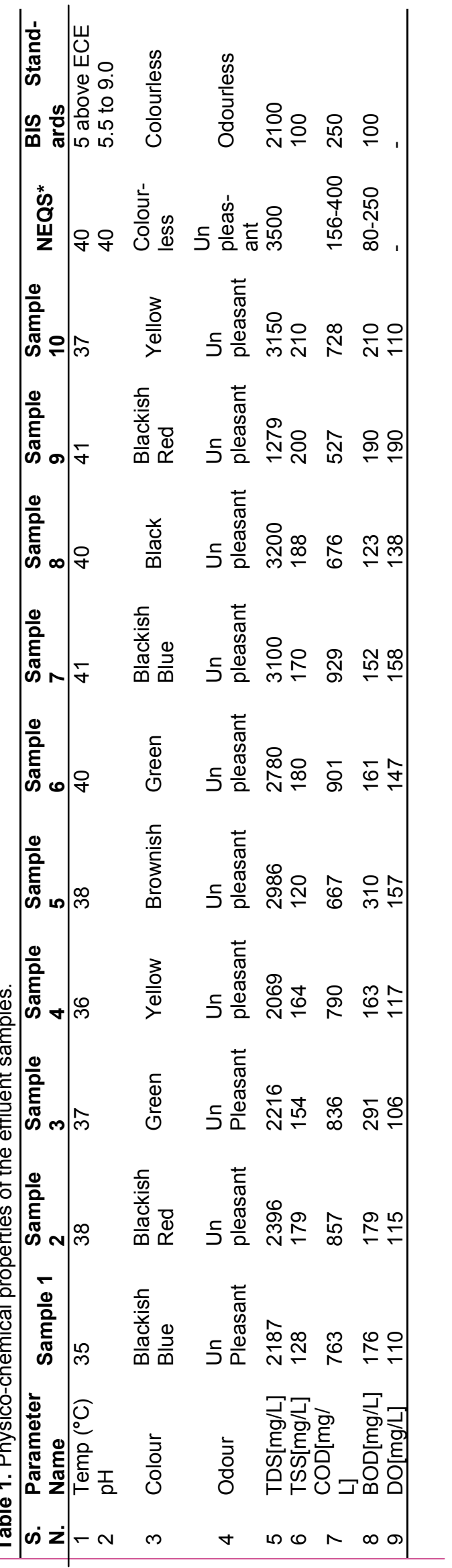


Table 2. Biochemical characterization of Isolated Bacillus species.

\begin{tabular}{lll}
\hline S.N. & Biochemical tests & Result \\
\hline $\mathbf{1}$ & Gelatin liquification & + \\
$\mathbf{2}$ & Starch hydrolysis & + \\
$\mathbf{3}$ & Lipid hydrolysis & + \\
$\mathbf{4}$ & Lactose fermentation & - \\
$\mathbf{5}$ & Dextrose fermentation & Acid production \\
$\mathbf{6}$ & Sucrose fermentation & Acid production \\
$\mathbf{7}$ & TiS & Acid production \\
$\mathbf{8}$ & $\mathrm{H} 2 \mathrm{~S}$ production & - \\
9 & NO reduction & + \\
10 & Indole production & - \\
11 & Methyle red reaction & - \\
12 & Vogesproskauer test & - \\
13 & Citrate utilization & - \\
14 & Urease activity & - \\
15 & Catalase activity & + \\
16 & Oxidase activity & + \\
17 & Casein hydrolysis & + \\
\hline
\end{tabular}

dye contaminated soil and effluent samples.

Identification of bacteria: In the present study, bacterial strains were isolated from effluents and soil samples near textile industries. On the basis of morphological, biochemical and 16s rRNA sequencing, the organism is identified as Bacillusspecies.

Morphological characterization of isolated colonies: The morphological characteristics of the isolated colonies were large gram-positive rods, arranged in chains.

Biochemical characterization of isolated Bacteria: Isolate subjected to biochemical tests and liquified gelatin, hydrolyzed starch, casein and lipid. It also fermented dextrose and sucrose (gas production), reduced nitrate, gives positive result to oxidase and catalase activity. It gives negative results for hydrogen sulphideproduction, Indole production, Methyle red reaction, Vogesproskauer test, Lactose fermentation and Citrate utilization. So by observing the results of biochemical tests the isolate is partially confirmed that belongs to Bacillus sp. (Table 2).

Based on morphological and biochemical reactions, the isolated organism belongs to Bacillusspecies. Similarly, HauwaTahiret al., (2016), isolatedStaphylococcus aureus, Bacillus cereus, Escherichia coli and Klebsiella pneumonia and identified based on their colonial, morphological and biochemical characterization. AmminiParavthi et al., (2009) isolated and identified Bacillus pumilusby detailed conventional biochemical methods, fatty acid methyl ester (FAME) analysis. Ali Ramadan Ali (2014) identified the bacteria based on molecular and biochemical characterization of bacterial isolates from food stall vegetables. Azharet al. (2017) identified cellulose degrading bacteria Anoxybacillus flavithermus, Van Veen et al. (2009) identified Staphylococci species and Sujatha et al. (2012) identified Bacillus thurin-

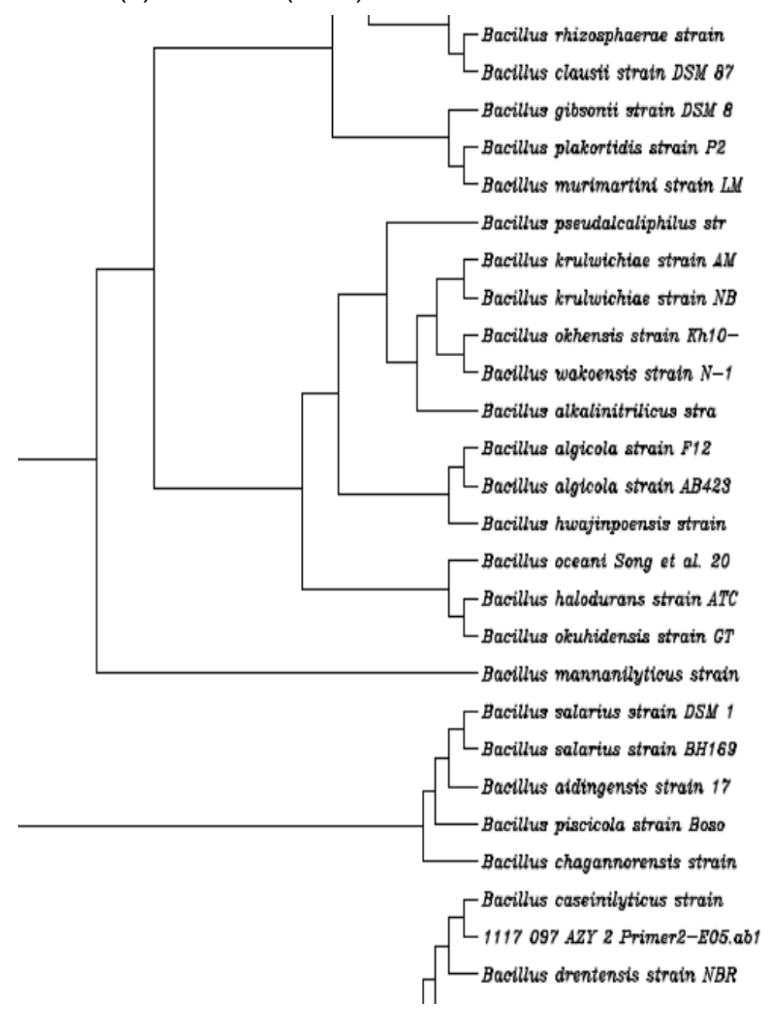

Fig. 1. Phylogenic tree of Bacillus species.

giensis, Streptococcus pneumoniae andBeuvinget al. (2011) identified b-hemolytic streptococci that belong to the viridans group. Isabel Sanchez, et al. (2000) identified Lactobacillus plantarum, L. brevis, L. fermentum, L. brevis, L. spentosus.

Molecular identification of the bacterial isolate: The selected isolate was identified by $16 \mathrm{~S}$ rRNA sequencing. The results cleared that the bacterial isolate is identified as Bacillus species exhibiting 99\% similarity. Fig. 1 shows the phylogenic relationship of $16 \mathrm{~S}$ ribosomal RNA gene, partial sequence of the isolated strainand species related to Bacillus species in the gene bank database. Similarly, Azharet al., (2017) identified cellulose degrading 4 bacterial isolates such as isolate 1 as 99\% similarity with Anoxybacillus flavithermus, isolate 2 has 99\% similarity with Bacillus megateri$u m$, isolate 3 has $99 \%$ similarity with $B$. amyloliquefaciens and isolate 4 was $99 \%$ similar with $\mathrm{Ba}$ cillus subtilis. Trupti (2009) isolatedTributyl phosphate degrading organism and sequenced and compared using BLAST, Clusta IW and PHYLIP, and the organism was identified as Pseudomonas alcaligenesstrain DSM50018Twhile Sujatha et al. (2012) identified $B$. thuringiensis strain IAM 12077using 16s rRNA sequencing.

\section{Conclusion}

The industrial effluents and soils contained enriched nutrients to grow and spread microbial population. Bacterial species have at least one copy of the $16 \mathrm{~S}$ rRNA gene containing highly con- 
served regions together with hyper variable regions. The use of $16 \mathrm{~S}$ rRNA gene sequences to identify new strains bacteria is gaining momentum in recent years. We showed the use of 16S rRNA gene sequence to characterize the bacterial isolate from the textile effluent and soil were found to be Bacillus sp.. Thus, the genotyping method using 16S rRNA gene sequence is both simple and effective in strain identification and the study concludedthat the isolate had adequate potential to decolorize the azo dyes- Red and Blue dye.Thus, the isolate could be exploited for its bioremediation ability.

\section{REFERENCES}

1. Ali Ramadan Ali, Latawi1, A. Sutarno1, Ari Susilowati1 and Hailu Weldekiros Hailu(2015).Biochemical and Molecular Characterization of Food Contaminating Bacteria Isolates from Food Stall Vegetables. British Microbiology Research Journal 5(5): 405-411.

2. AmminiParvathi, Kiran Krishna, JiyaJose, Neetha Joseph. And SanthaNair.(2009). Biochemical and Molecular characterization of Bacillus pumilis isolated from coastal environment in Cochin, India.Brazilian Journal of Microbiology (40):269-275.

3. Andre, B.D.,Fransisco, J.C. and Jules,B.L. (2007). Review paper on current technologies for decolourization of textile effluent. Colourage,(40): 35-38.

4. Aneja, K.R. (2004). Experiments in Microbiology. New Age International (P) Limited Publishers, (4).

5. Azhar A. Hussain, Mohamed S. Abdel-Salam, Hoda H. Abo-Ghalia, Wafaa K. Hegazy, Safa S. Hafez (2017). Optimization and molecular identification of novel cellulose degrading bacteria isolated from Egyptian environment. Journal of Genetic Engineering and Biotechnology 15: 77-85.

6. Beuving, J., Christina, F.M., van der Donk., Catharina, F.M., Linssen Petra. F.G. Wolffs. andAnneliesVerbon. (2011).Evaluation of direct inoculation of the BD PHOENIX system from positive BACTEC blood cultures for both Gram-positive cocci and Gram-negative rods. BMC Microbiology, 11:156.

7. Gogate.P.R., and Pandit.A.B., (2004). A review of imperative technologies for wastewater hybrid methods. Adv. Environ.Res., 8: 553-597.

8. Hauwa Tahir, ZuwairaDanyaro, Halima Ladan, Sanusi Magaji (2016). Isolation and identification of Bacteria Involved in the Contamination of Some selected Fast foods Solid Within Wutin dada area, Bauchi. International Journal of Advances in Science Engineering and Technology, 4, (4).

9. Holding, A. J. and Collee, J. G. (1971). Chapter I Routine biochemical tests. In Methods in microbiology (Vol. 6, pp. 1-32). Academic Press.

10.Isabel Sa'nchez, Llanos Palop, and Cristina Ballesteros. (2000). Biochemical characterization of lactic acid bacteria isolated from spontaneous fermentation of 'Almagro' eggplants. International Journal of Food Microbiology, 59: 9-17

11.Laowansiri, Sunantha, SoydoaVinitnantharat, PawineeChaiprasert, and SungRyongHa. (2008). Anaerobic degradation kinetics of reactive dye with differentcarbon sources. J. Environ. Biol., (29): 309-314.
12.Manikandan, N., SurumbarKuzhali, S. and Kumuthakalavalli, R. (2012).Decolorisation of textile dye effluent using fungal microflora isolated from spent mushroom substrate (SMS). J. Microbiol. Biotech. Res, 2 (1): $57-62$

13. Mathur, Nupur.andPradeepBhatnagar.(2007). Mutagenicity assessment of textiledyes from Sanganer (Rajasthan). J. Environ. Biol., (28): 123-126.

14.Nigam, P. Armour, Banat. G., Singh, I.M., Marchant, D., McHale, R., McMullan, G. (2000) Physical removal of textile dyes from effluents and solid-state fermentation of dye-adsorbed agricultural residues. BioresTechnol., (74):179-179.

15.Pant Deepak, Anoop Singh, YaminiSatyawali, and Gupta, R.K. (2008). Effect of carbon and nitrogen source amendment on synthetic dyes decolourizing efficiency of white-rot fungus, Phanerochaete chrysosporium. J.Environ. Biol., (29): 79-84.

16.Rajeswari, K., Subashkumar, R. and Vijayaraman, K.J. (2013). Physico chemical parameters of Effluents collected from Tirupur Textile dyeing and CETP and analysis of Heterotropic bacterial population. Journal of Microbiology and Biotechnology Research, 3(5): 37-41

17.Robinson, T., McMullan, G.andNigam, P. (2001).Remediation of dyes in textile effluent: a critical review on current treatment technologies with a proposed alternative.Bioresource Technology, (77): 247-255.

18.Sofia Nosheen, Haq Nawaz and Khalil-UR-Rehman, (2000). Physico-Chemical Characterization of Effluents of Local Textile Industries of FaisalabadPakistan. International Journal of Agriculture and Biology, 2(3): 232-233.

19.Sriram, N. and Reetha, D.(2015). Isolation and characterization of dye degrading bacteria e effluents. Central European Journal of Experimental Biology, 4 (2):5-10

20.Stolz, A. (2001). Basic and applied aspects in the microbial degradation of azo dyes. Appl. Microbiol. Biotechnol., (56): 69-80.

21.Sudha, M., Saranya, A., Selvakumar, G. and Sivakumar N.(2014).Microbial degradation of Azo Dyes: A review Int.J.Curr.Microbiol.App.Sci, 3(2): 670-690.

22.Sujatha, P., Naresh Kumar, B.andKalarani, V. (2012). Isolation, characterization and molecular identification of bacteria from tannery effluent using $16 \mathrm{~S}$ rRNA sequencing. Current Biotica, 6 (2): 198-207.

23. ThokerFarook Ahmed, Manderia Sushi, and Manderia Krishna. (2012). Impact of Dye Industrial Effluent on Physicochemical Characteristics of Kshipra River, Ujjain City, India International Research Journal of Environment Sciences, 1(2): 41-45.

24. Trupti D. Chaudhari, Susan Eapen and Fulekar1, M. $H$. (2009). Characterization of industrial waste and identification of potential micro-organism degrading tributyl phosphate Journal of Toxicology and Environmental Health Sciences 1(1): 001-007.

25.Van Veen, S. Q.,sClaas, E. C. and EdKuijper, J. (2010).High-Through put Identification of Bacteria and Yeast by Matrix-Assisted Laser Desorption Ionization-Time of Flight Mass Spectrometry in Conventional Medical Microbiology Laboratories. Journal of Clinical Microbiology, 3(48): 900-907. 